\title{
Research with Children
}

\section{Sultana Ali Norozi}

\section{Torill Moen}

\author{
Department of Education and Lifelong Learning, Norwegian University of Science and Technology \\ Trondheim, Norway; Email: sultana.a.norozi@svt.ntnu.no
}

\section{Doi:10.5901/mjss.2016.v7n3p397}

\begin{abstract}
The understandings and concepts about children and childhood have an impact on the directions of child research. Research with children becomes very crucial in order to have exact understanding of children's lives. Based on the issues involved in research with children the purpose of this paper is to present and explore theoretically, the ideas and arguments, being offered about differences between research with children and adults. Therefore with a wide description of literature about the key issues involved in research with children, the theoretical paper begins with a brief account on what is written about research with children. To elucidate the notion "research with children" the discussion will consider research 'on' 'about' 'with' and 'by' children. Further, to sketch the differences between research with children and adults, a deep exploration of the subject is bound up in three points: power dynamics, methodologies and ethical issues. Assenting that there are differences between research with children and adults, some measures derived from theoretical discussion conclude the paper.
\end{abstract}

Keywords: child; childhood; research with children, differences between research with children and adults.

\section{Introduction}

The social studies of children and childhood have strongly argued for the value of studying children in their own right and from their own perspectives (Christensen \& James, 2008; Kjørholt, Moss \& Clark, 2005). This is done by involving children directly in research and science. The true knowledge can only be constructed by considering children as most significant research unites in science. This leads to the fundamental point about the status of children in research and theory. Yet, children are ascribed lower status due to incompetency of adults to understand children's praxis. Delegation of such status to children has its impact when it comes to their involvement in research. It results to embrace differences between research with children and adults.

\section{Theoretical Research Questions}

Based on the notion of research with children, the paper aims to present and explore theoretically, the main influences and arguments being offered by researchers within the paradigm of child research about:

- What is "research with children"?

- In what ways research with children differ from research with adults in regard with power dynamics, methodology and ethical issues?

\section{Methodology}

"There are various ways of approaching the study of childhood as a social phenomenon. One of the ways is to review literature" (Mayall 2002, p. 9). The theoretical paper uses the approach of literature review to answer the above questions.

\subsection{What is "Research with Children"?}

"A crucial source of knowledge and understanding about childhoods and children's lives comes from research" (Kellett 2010, p. 6). The contemporary research practices with children engender complexity of epistemological and methodological concerns. It is substantial to explore such concerns in a context where researchers are increasingly striving to confront the theoretical and policy implications of treating children as social actors in their own right. Christensen \& James (2008) invoke that these concerns in research with children are linked with the understanding about 
children. Conversely it's research with children which generates new knowledge and understanding about children. Thus research with children as a structural feature of a society remains a vital consideration. In regard with understanding about children, they postulate broadly the issues of child-adult distinction and child's identity. With consideration of these concerns, Woodhead \&Faulkner (2008) mentioned the six key issues while involving children in research:

- The suitability of research design

- The construction of childhood in relative context

- Children's own perspectives about research context

- The power relation between researcher and researched

- Consideration of ethical issues

- The status of children in research

Children are delegated subordinate status in adult-led society due to adults' ignorance of children's competences. Solberg (1996), as do others, argues that children are experts on their lives and adults need to learn the ways to understand children's competences. Secondly the 'child' is not fixed universal category. It challenges the collectivization of children within a minority status. So such issues lead to place differences between research with children and adults.

\subsection{Research 'on', 'about', 'with' and 'by' children}

The first question of the paper deals with why it is used research "with children" and not "about" or "on" children. It deals with simple as well as complex explanations some of which are presented here. "Research involving children can be expressed as four typologies: research on children; research about children; research with children; and research by children" (Kellett 2010, p. 22). Research involving children depends on the understanding of how children and childhood are understood. So as the understanding about children changed over time it affected the role of children in research. In early developmental psychology experiments children were used as research objects. In such laboratory-style research, developmental psychology focused on cognition and stages of development. Children were objects of adult research. And knowledge was gained from research on children.

An increased focus on research about children as a social category emerged as a result of a shift towards an understanding that the notion of children and childhood is socially constructed. With the new understanding of children, anthropologists and sociologists in particular, began to question the role and relationships of children and research. And this led the role of children in research from 'on' and 'about' to 'with'. About emerging role of children in research, Nilsen (2005) comments "in recent years, a whole range of qualitative studies have aimed at giving children and young people a voice in research through using an actor perspective with children as informants" (p. 120). This means that new way of involving children in research urges for major recognition of children in research.

The social studies of children and childhood challenged the argument that children are not competent enough to undertake their own research. Children are empowered to select topic of research from any aspect of their lives which they consider important. They choose the method and design to lead their own research. They are equally and actively engaged in analysis and making sense of their findings. Further they are the body to disseminate their findings. In this way the research is done with children's perspectives rather than adult-led child research. "The increasing focus on children as social actors and capable agents foster more research by children themselves" (Kellett, Robinson \& Burr 2006, p. 38). Without children's perspectives there cannot be reliable knowledge about children derived from research.

\section{Theoretical Discussion}

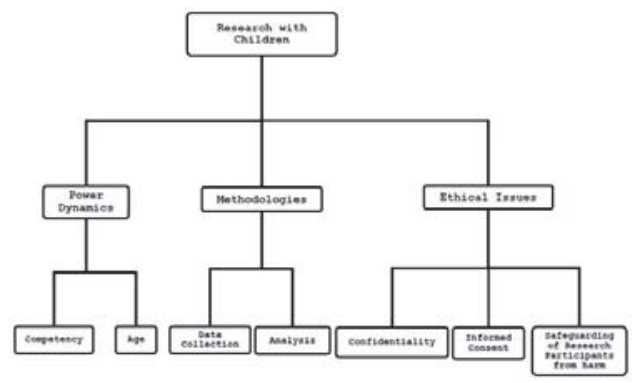

Figure: Differences between research with children and adults

Source: Developed for this paper 
This section of the paper moves to consider the differences between research with children and adults. In order to appreciate the differences between research with children and adults, research by children will be included in research with children's entity. There are many other research issues for example developing rapport, validity and reliability, research context and clarity of research question, which could be regarded with the notion. However the description and discussion presented here will be bound up in three points:

- Power dynamics

- Methodologies

- Ethical issues

\subsection{Power dynamics}

As Woodhead \& Faulkner (2000) explain that "the research process is generally controlled by researchers (adults) not children" (p. 12). In research there is always a power relation between a researcher and informants. However the degree of acceptance of power relationships to which both children and adults are subject is different. While highlighting the role of researcher, Tingstad (2007), explains that it is not the methods rather ontology and epistemology that drives the research. It is of vital importance that how one understands and interprets the world and how one chooses to obtain knowledge about it. Thus the researcher's position in relation to these issues is crucial to entire research process, from defining the topic, the research problem and methods, to the analysis, interpretations and conclusion of the study ( $p$. 129).

It explains that it is researchers (adults) who have control on all aspects of research for example selection of research topic, formulating research questions, designs and methods, analysis and dispersion of findings. Informants both children as well as adults have very little to do in this. The major role of informants is in data collection but very rarely or almost no involvement in analysis of their data. This is same in both researches i.e. research with children as well as research with adults.

However there are some aspects which make power dynamics in research with children different from power dynamics in research with adults. Among those competency and age are counted as defining factors in making research with children different from research with adults.

\subsubsection{Competency and Age}

"The key perceived difference between children and adults in research is children's assumed lack of competence: competence to make decision about whether to participate in research, and competence to provide valid sociological data" (Morrow \& Richard 1996, p. 98). On the other hand, as Woodhead (2008) explains that in research process the power relationships are weighted towards researcher as the expert on children. He states "children have been subject of scientific enquiry for more than a century, research was largely shaped by adult agendas for children, and reflected dominant power relationships between expert researchers and innocent, vulnerable, developing children" (p. 23). While presenting macroanalysis of childhood(s) Qvortrup (2000) considers three possibilities which produce childhood(s) and children competencies. They involve three comparisons: historical comparison and intercultural comparison and comparison between countries and between generations. Mostly children are kept in spaces which are specialized for them for example school and kindergarten etc. This limitation leaves children with limited understanding of society in which they live. If children don't have access and exposure then the context and situation will not make sense to them. "Children's true competences are revealed only in situations which make sense to them" (Woodhead \& Faulkner 2000, p. 24). Thus children's knowledge can be disregarded and can be controlled by adult force. In research with adults, on the other hand, adults' accessibility is to the whole society and every possible space. Such exposure and accessibility is one of the factors for so called better competencies of adults.

The belief that adults have better competencies widens child-adult power relations. It is not due to children's inabilities rather due to the status ascribed for children by adults. However the view is changed overtime. The competency factor was very dominating in early days of developmental psychology. Yet in the social studies of children and childhood, children's competencies are accepted as different rather than inferior. It is acceptable in some aspects of life but when it comes to children then it is children who have the superior knowledge (Mayall 2002).

The power dynamics has another fold when it comes to research by children. In research by children though it is children who carry out the research, however as Qvortrup (2009) asks, to what extent research by children inform policies? The paradigm shift in the social studies of children and childhood stresses that research by children is valuable and worth to inform policies. Then this bewilders that our social and educational policies are not based on reality as they 
are not rooted with children's own perspectives. To condense this perplexity Woodhead \& Faulkner (2000) suggest that this can be seen as productive and progressive if the whole process is accounted in historical and cultural contexts in which those researches have been carried out.

\subsection{Methodologies}

"What is important is that the particular methods chosen for a piece of research should be appropriate for the people involved in the study, for its social and cultural contexts and for the kinds of research questions that are being posed" (Christensen \& James 2008, p. 3). In research with adults any methodology can be used unless it is aligned with research question, cultural and social contexts. While the emerging paradigm shift in the social studies of children and childhood emphasizes that not all research methods are for children. And this presents the huge difference between research with children and research with adults.

\subsubsection{Data collection}

Punch (2002) mentions that somehow it tends to mislead within the new sociology of childhood that on one hand it is emphasized on children as competent social actors. On the other hand, it is accentuated for the use of innovative and adapted research techniques with children. "If children are competent social actors, why are special 'child-friendly methods needed to communicate with them?" (p. 221). The agreed understanding in children's new sociology informs that children can be at their best competencies' level only when they can make sense of situations around them (Mayall, 2002; Christensen \& James, 2008; Solberg, 1996; Kjørholt, Moss \& Clark, 2005; Woodhead \& Faulkner, 2000; Qvortrup, 2000; Fraser, 2004; Nilsen, 2005). Alternatively, as Fraser (2004) explains that such special methods could mean to effort to engage children in research in such a way which make better sense for them. For example the use of relevant vocabulary is very crucial in this regard. However this is same while conducting research with adults. It is not necessary that all adults have better vocabulary than children. However adults have more range of experience than children. Nevertheless, it is arguable that some children have more experience and a better capability with different languages than some adults. It is researchers' obligation to use vocabularies which make sense for both children as well as adults when involved in research. Conversely researchers may lack specific knowledge of the concepts used by children. As Punch (2002) refer that younger children may have limited vocabulary but they use different way of communication which adults do not understand. For example understanding of drawings by children in their own ways may be equally challenging for adults to understand. So this dilemma of communication is mutual.

Particular types of data collection methods such as drawings, photography, dairies, storytelling, mosaic, painting, singing and other innovative techniques are used while undertaking research with children (Clark 2005). Before deciding for any particular type of method, negotiations must be done. Alike adults, children are different in their competences and facilities. Hence children must not be treated as homogenous mass (Fraser 2006). So Fraser answers Punch's (2002) question by calling such methods as 'participant-friendly' rather than 'child-friendly' ( $p$. 25). Research with adults also needs to have appropriate methods in accord with adult informants' capabilities. So "researchers need to develop ways of engaging children in a wide range of different circumstances, including those with special educational needs and disabilities, in order to obtain quality information that is not otherwise available (Masson 2004, p. 45). On the other hand, Woodhead \& Faulkner (2000) discuss the use of same methods for both children and adults. This is based on the notion to focus on children's perspectives of an adult world in which they are required to participate. The idea here is basically to perceive that children are the same as adults and the same research methods can be used for example interviews, questionnaire surveys etc. However the drawback with this line is that it does not address the difference between adult and child subjects in terms of social status. Asking children about things they have not experienced will pave way to view them as incompetent and unable to understand.

\subsubsection{Analysis}

Reinforcing many other researchers, Mayall (2002) discusses some of the perceived drawbacks while collecting data with and by children. For example children are considered that they can't tell truth from fiction, children make things up to please the interviewer, children do not have enough experience or knowledge to comment on their experience and they will tell what they have been told by adults. However she adds that all of these problems equally apply when collecting data from adults. To Mayall the real difference lies at the level of interpretation of data. In research with children, interpretation of data demands different knowledge than that generally possessed by adult researchers. As Qvortrup 
(2000) highlights that it is equally important to have children's interpretation on data collected. Sometimes the interpretations are far away from what children meant and rarely returned to those children to confirm. So researchers need to respect children's competencies and put aside their adult tendencies. In doing so there might be some challenges from those who still see children as objects of protection. However it should be cautioned, as Woodhead \& Faulkner (2000) go on saying that:

\begin{abstract}
"Displacing an image of the developing child as subject with an image of the participating child must not result in the neglect of differences between younger [children] and older human beings [adults]. We must not throw out the baby with the developmental bathwater. Respect for children's status as social actors does not diminish adult responsibilities. It places new responsibilities on the adult community to structure children's environment, guide their behavior and enable their social participation which is consistent with their understanding, interests and ways of communicating, especially in the issues that most directly affect their lives" (p. 31-32).
\end{abstract}

Nilsen (2005) illustrates the necessity of reflexivity in the analytical process while conducting research with children as main informants in Norwegian day-care centres. She establishes her illustration and discussion in relation to two approaches of analyzing empirical data. First one is top-down approach where established theoretical concepts are applied. Second one is bottom-up approach where theoretical concepts grounded in empirical data are generated. Referring to Glaser \& Strauss's (1967) fit of empirical data and theoretical concepts, Nilsen emphasizes the subject status of children generating and applying dynamic concepts in undertaking analytical part of research. She alludes "ensuring the subject status of children also involves reflexivity in the process of analyzing the data, how we conceptualize the actors in the concepts we choose and whether these are established ones that we 'import' and adapt or are concepts we ground and generate from our data" (p. 130).

When it comes to research by children one of the challenges is children's lack of analytical research knowledge and skills. Yet it is same in case of adults too as adults also lack research skills and knowledge. Both children and adults need proper training in order to undertake their own research. This demands for both human and physical resources. Such needs lead to a question that are children in every part of the world can do their own research? (Alderson 2001)

\title{
4.3 Ethical issues
}

"Ethical issues are often thought to be the central differences between research with children and research with adults" (Punch 2002, p. 323). The paper focuses on three points of consideration among ethical issues namely:

- Informed consent

- Confidentiality

- Safeguarding of research participants from harm

\subsubsection{Informed consent}

Informed consent is one of the important parts of research both with children as well as adults. The similarity is that both children as well as adults need to have clear understanding of what is involved in the research. Or in other words what exactly they are consenting to. This is called informed consent. Sufficient knowledge about every aspect of research needs to be provided in a way which is easy for participants to understand. So for children it must be considered that the information must be provided in such a language and a way that is acceptable and understandable for children (Christensen \& Prout, 2002; Morrow \& Richards, 1996).

The issue of difference about informed consent in research with children and adults is complex. This is because of understanding about child's status in research. According to Masson (2004) the access to children for research was usually obtained via gatekeepers i.e. legal guardians. So only their legal guardians were consulted for informed consent. It happened to limit researchers' access to children. Also researches were done mostly in captive environment, such as schools, where a head teacher and/or a teacher was considered for consent. However with the emergence of new paradigm in childhood studies it is considered to have consents from both children as well as legal guardians. Getting consent from legal guardians and children at the same time can lead to a conflict where children may wish to participate in a study but parents refuse and vice versa. Referring to child law and interaction between child law and social work, Masson adds that in "such circumstances where failing to check child's willingness to participate could undermine the research process .... or it would be unethical (p. 49). 


\subsubsection{Confidentiality}

Christensen \& Prout (2002) highlight that it is researcher's ethical duty to protect participants' identity from public scrutiny. To this extent, children in research are treated as same as adults. However, children are more concerned about their responses (which can be in form of words, drawings, photos etc.) being taken back to their guardians and/or teachers. Here confidentiality goes a step ahead and researchers are supposed to guarantee about it. If the total confidentiality cannot be guaranteed then researchers need to be honest with children about it. Often, complete confidentiality is not possible particularly in research interview whether it is with a child or an adult. So such situations need to be negotiated with informants.

Due to less experience children have less expectations of confidentiality from researchers. At times it is hard to think how the current research will affect a child's future. The words and actions which a child of six years does not care today, can be important or embarrassing tomorrow in teenage. Kellet (2010) reinforces the idea that "children tend to focus on immediate questions about confidentiality such as who will listen to the tape, whether parents will be allowed to read the interview transcripts and when and how the tape will be destroyed" (p.29). However as Masson (2004) reinforces that it must be conveyed to children clearly that no one will react as a result of what a child has told the researcher. Also research cannot take any action that makes a difference to the child's life. The research may intend to improve provision for children but no researcher can offer this in return for consent. If improvements are made, ethically these should be provided to all, not just for those who agreed to participate.

While highlighting the ethical issues in social research with children, Morrow \& Richards (1996) explain that there is no huge distinction about anonymity between research with children and adults. However it is important to consider the short as well as long term consequences for using the real names of children. It is vital to note that the child has thought through the possible implications in future. Sometimes a conflict can arise when legal guardians want to have the real names of participating children while children themselves do not want to reveal their identities and vice versa. In such situations the role of the researcher becomes critical. It needs to be negotiated with gatekeepers to respect children's decisions about anonymity.

\subsubsection{Safeguarding of research participants from harm}

Safeguarding of research informants from harm is same for both research with children and adults. However children are more vulnerable in some situations. As Kellett (2010) emphasizes "it is vital that any research process whether this involves children as participants or as researchers in their own right does not cause harm. Harm can be physical, mental or emotional" (p. 30). Mental and emotional harm is hard to recognize as compare to physical harm. It is easier for an adult researcher to think of potential mental and emotional harm for an adult as compare to children. Tackling with such is challenging for an adult researcher. What measures a researcher can take in order to make sure to think of harm with children's perspectives.

Physical arrangement as well as environmental factors must be taken care while undertaking a research with children. It requires extra considerations of place where children are involved in research. It is vital to make sure that children are comfortable and relaxed throughout the process. The surroundings must be 'participant friendly' where children be there with their own choice without any force, threat and/or greed. Most importantly children feel and be safe during the whole process of research (Masson, 2004).

Involvement of children in research as researchers raises more concerns about children's safety in research. Children who are engaged as researchers should be treated as respected as adult researchers. Yet it is not enough even to treat children as adults rather it must be made sure that the research throughout is led by children's understandings not of adults at any point. Relying only on general ethical law which provides a general ethical framework for research is not enough. In research by children, purely children's perspectives should be considered in regard with safeguarding their informants from harm. Yet the general ethical framework could be used as base from which to develop a line that respects the individuality and personhood of children in their own rights and perspectives (Alderson, 2001; Masson, 2004).

\section{Conclusion}

There are some differences between research with children and adults but differences are not due to any incompetency of children. Considering children's competencies different rather than seeing children as incompetent leads to have 'participant friendly' techniques. The concept of 'participant friendly' implies equally when it comes to research with adults. As rightly mentioned by Christensen \& James (2008) that "grownups cannot, on their own, understand the world from the 
child's point of view and therefore they need children to explain it to them" (p. 9).

While dealing with ethical issues children are to be privileged as same as adults. Children have full rights to consent for themselves. And before gaining consent all possible significances and consequences in present as well as in future must be clarified. According to Christensen \& Prout (2002) when it comes to address the ethical issues with children then code of ethics and collective professional responsibility are important to meet ethical issues that flow from new emerging paradigm of children's sociology and childhood studies. Christensen \& Prout suggest that dialogue is required on two levels: between researchers as a mean of collective sharing experience and between researchers and children in ongoing research process. Ethics committees can also be helpful. While conducting research with children, ethics committees not only advise but also observe the ethical practices. With the increasing trend of research by children, it is important to consider special ethics committees being formed to support child researchers.

\section{References}

Alderson, P. (2001). Research by children. The international journal of social research methodology 4(2), 139-153.

Christensen, P. \& Prout, A. (2002). Working with ethical symmetry in social research with children. Childhood, 9(4), 477-497. In P. Christensen, \& A. James (Eds.), research with children: Perspectives and practices (pp. 9-35). London: Routledge Flamer.

Christensen, P. \& James, A. (2008). Introduction: Researching children and childhood cultures of communication. In P. Christensen, \& A. James (Eds.), research with children: Perspectives and practices (pp. 1-9). London: Routledge Flamer.

Christensen, P. \& James, A. (2008). Childhood diversity and commonality: Some methodological insights. In P. Christensen, \& A. James (Eds.), research with children: Perspectives and practices (pp. 156-172). London: Routledge Flamer.

Clark, A. (2005). Ways of seeing: using the Mosaic approach to listen to young children's perspectives. In A. Clark, P. Moss \& A. T. Kjørholt (Eds.). Beyond Listening: children's perspectives on early childhood services. (pp. 29-49). Bristol: Policy Press.

Fraser, S. (2004). Situating empirical research. In S. Fraser, V. Lewis, S. Ding, M. Kellet \& C. Robinson (Eds.), Doing research with children and young people (pp. 15-26). London: SAGE Publications Ltd.

Fraser, S. \& Robinson, C. (2004). Paradigms and philosophy. In S. Fraser, V. Lewis, S. Ding, M. Kellet \& C. Robinson (Eds.), Doing research with children and young people (pp. 59-77). London: SAGE Publications Ltd.

Kellett, M. (2010). Introduction. In M. Kellett (Ed.), Rethinking children and research: attitudes in contemporary society (pp. 5-9). London: Continuum.

Kellett, M. (2010). The issues and debates defined. In M. Kellett (Ed.), Rethinking children and research: attitudes in contemporary society (pp. 10-32). London: Continuum.

Kellett, M. (2010). Children and young people as researchers. In M. Kellett (Ed.), Rethinking children and research: attitudes in contemporary society (pp. 104-123). London: Continuum.

Kellett, M., Robinson, C. \& Burr, R. (2006). Images of childhood. In S. Fraser, V. Lewis, S. Ding, M. Kellet \& C. Robinson (Eds.), Doing research with children and young people (pp. 27-42). London: SAGE Publications Ltd.

Kjørholt, A. T., Moss, P. \& Clark, A. (2005). Beyond listening: future perspects. In A. Clark, A. T. Kjørholt \& P. Moss (Eds.), Beyond listening. Children's perspectives on early childhood services (pp. 175-189). Bristol: The Policy Press.

Masson, J. (2004). The legal context. In S. Fraser, V. Lewis, S. Ding, M. Kellet \& C. Robinson (Eds.), Doing research with children and young people (pp. 43-58). London: SAGE Publications Ltd.

Mayall, B. (2002). Relations with parents. In B. Mayall (Ed.), Towards a sociology for childhood (pp. 42-62). Buckinggham: Open University Press.

Mayall, B. (2002). Studying Childhood. In B. Mayall (Ed.), Towards a sociology for childhood (pp. 9-26). Buckinggham: Open University Press.

Morrow, V. \& Richards, M. (1996). The ethics of social research with children: An overview. Children and society 10 (1996), 90-105.

Nilsen, R. D. (2005). Searching for analytical concepts in the research process: learning from children. The international journal of social research methodology $8(2), 117-135$.

Punch, S. (2002). Research with children: the same or different from research with adults? Childhood 9 (3), 321-341.

Qvortrup, J. (2009). Childhood as Structural form. In J. Qvortrup, W. A. Corsaro \& M-S. Honig (Eds.), Palgrave handbook of childhood studies (pp. 21-33). London: Palgrave.

Qvortrup, J. (2000). Macroanalysis of childhood. In P. Christensen, \& A. James (Eds.), research with children: Perspectives and practices (pp. 77-97). London: Routledge Flamer.

Solberg, A. (1996). The challenge in child research: From 'being' to 'doing'. In B. Julia, \& O' B. Margareth (Eds.), children in families: research and policy (pp. 53-64). London: Flamer Press.

Tingstad, V. (2007). New technologies, new methods?: Representing children in online and SMS ethnography. In K. M. Ekström, \& B. Tufte (Eds.), children, media and consumption: On the front edge: yearbook 2007. (pp. 27-143). Göteborg: Nordicom, Göteborg universitet.

Woodhead, M. \& Faulkner, D. (2000). Subject, object and participants? Dilemmas of Psychological research with children. In P. Christensen, \& A. James (Eds.), research with children: Perspectives and practices (pp. 9-35). London: Routledge Flamer.

Woodhead, M. (2008). Childhood studies: past, present and future. In K. M. Jane (Ed.), introduction to childhood studies (pp. 17-31). Berkshire: Open University Press. 